UDC 81

DOI https://doi.org/10.32838/2710-4656/2021.6-2/02

Alizada L.

Tourism and Management University

\title{
GLOBAL SPREAD OF ENGLISH AND ITS IMPACTS ON TOURISM LEXICOLOGY
}

The purpose of the article is to investigate the importance of English as a global language in the professional context of the tourism industry and its influence on lexicology.

Methodology and methods used: the study used general scientific and private (linguistic) methods. For the study there were selected and analysed the most popular borrowed tourist words according to free Internet resources. While researching various sources, a number of studies have been conducted on the words taken in the field of tourism in global English. Different linguists have been cited to define the status of English with overviewing its history and its role in tourism sector. One of the interesting features of this study is the study of the etymological origin of the words and phrases related to the field of tourism. 26 tourism related terminological units taken from different sources have been analyzed and lexical semantic division has been introduced to get clear understanding of the topic.

The main scientific innovation. The rapid development of technologies, marketing, advertising, scientific development of sciences opens broad ways in the expansion of a language around the world. The growing interest in tourism in the 21 st century is considered a major factor in the rapid globalization of the English language in recent years. This new process, which leaves its mark on the language, attracts the special attention of linguists. In this regard, there is a growing need for new researches in this area. Taking into account all factors, this research is of scientific importance.

The following results were obtained in the article: in the twentieth century, tourism became a serious global policy, and consequently, with the development of international mass tourism, a new stage was opened in the formation of international tourism organizations. The global status of English played a crucial role in this process. Consequently, English has achieved global status, and it is widely used by different people to understand each other and to exchange ideas. Thus, I claim in this paper that in the global world to communicate, to negotiate, and to make contacts between the tourists and the tourism-employees, the role of English is indispensable.

Key words: globalization, global language, tourism, global status, international mass tourism.

1. Introduction. English is the language of international tourism, and travel is the constituent part of global life. G. Dann expresses it as: "The use of English iconically transcends [national and linguistic] confines and passes into a mystical, global unbounded realm where nothing but the sky is the limit... the implied reader of bilingual advertisements is not a national citizen but a transitional consumer [1, p. 2].

As it has already been established, English is the most widely spoken foreign language throughout Europe and the whole world. The reliance on English as a means and symbol of global communication is unique to some spheres. The globality of English is defined differently by different linguists. For instance, P. Cook [2] refers to the "worldliness" of English, and House [3] describes it as "a language for communication". So, language has great importance in communication between tourists and local people. The global status of English makes the role of this language essential in the tourism industry.
Better understanding accelerates communication and decision making through language. The language of the tourism attracts, persuades, and encourages potential tourists to become actual tourists. In this association, language is utilized as a discourse object.

D. Crystal [4] defines the present-day world status of English as the result of two factors: "The expansion of British colonial power, which peaked towards the end of the nineteenth century, and the emergence of the United States as the leading economic power of the twentieth century. It is the latter factor which continues to explain the world position of the English language today". In the twentieth century, tourism became a serious global policy, and consequently, with the development of international mass tourism, a new stage was opened in the formation of international tourism organizations. In the tourist destinations of the world, the signs in the shop windows are most commonly in English; restaurant menus present the English version. Therefore, in this paper, we sketch out key research in the language in use and tourism. 
2. Review of literature. The variety of ways in which the English language relates to tourism has attracted much attention of linguists within a range of fields of study. This article discusses the ways in which the English language relates to tourism laying particular emphasis on the role language plays in revealing much about how tourism as a system depends on the use of language.

Firstly, the author of the book "English as a global language", D. Crystal, is entirely unimperialistic and stresses the importance of English developing as a vehicular language alongside other languages, not instead of them. However, as the world's leading expert on the globalization of English, D. Crystal's views concerning the issue draw world linguists' attention.

Certainly, there have been some studies that have researched the linguistic features of tourism promotion; some brought them together and systematically examined tourism as a language.

G. M. S. Dann is one of the best-known authors in the field of tourism language. He has investigated the language of tourism and the way it helps to "convert... [tourists] from potential into actual clients" [5]. Some scholars argue that, according to Dann, tourism language is characterized by social control and thus aims "to persuade people to become tourists and subsequently to control their attitudes and behavior, through pictures, brochures, and other media".

I have used different linguists' theories as the basis of my research. But in some points, I referred to scholarly articles written by different researchers. Introduced data is taken from websites of WTO (World Tourism Organization), the Hotwire Group, and Expedia CruiseShip Centers.

However, a careful investigation into the relationship between tourism and the language of tourism is still in need.

3. Methods. In order to investigate the relationship between the global language and tourism, different works of linguists are analyzed. Drawing any definitive conclusion from these various surveys is very difficult. The viewpoints are very different.

In the first part of our investigation, we give a description of the English language from historical points of view. Our research is based on D. Crystal's book "English as a Global Language" [4].

The second phase of our investigation encompasses the research made into the factors that define the current status of English. In this part of research various tourism terms taken from different sources are analyzed from lexical, grammatical and semantical points of view.
In the third phase of research, we try to overview the history of tourism. Here we clarify the development stages of the tourism industry, beginning with the formation of the first tourism agency in 1758, the emergence of railways, an automobile, airplanes, later reaching into the pick level with the introduction of online travel services.

In the fourth and fifth parts of investigation, we make an attempt to explain the role of the English language in tourism management and utilization of it in different tourism destinations. In this phase, we try to prove that ignoring the important roles of the English language may result in the failure of the tourism sector. Therefore, English influences the organization's ability to control international activities.

Finally, in the last part of investigation, with the help of lexical units taken from different tourismrelated texts, we introduce the lexical-semantic group division. According to the driven analysis, we define the occurrence frequency of tourism terms and influence of globality of English to the tourism industry.

\section{Results and discussion.}

1.1. The global spread of English. English as a foreign language and major lingua franca has now spread into most European countries all over the world as a language of tourism, alongside the official national languages. Why not other language but English? Why has English become global? What is its peculiarity? In order to find the answer to these questions, we must look through the history of this language and analyze all the stages of its formulation.

It is not true that the number of people speaking defines it as a global language. Latin was the leading international language throughout the Roman Empire. However, it did not depend on the number of Romans. The number of people they subjugated was more than their own people. Therefore, we can come to the conclusion that the status of the language was determined by the power of people who use it [6]. The language also has close links with economic, cultural, technological powers. If we want to clarify the reasons for the dominance of English, it would be better to look at the history of English.

Let's find the origins of Global English. One of the main features of English is that it is always on the move. In the fifth century, it moved towards England and began to spread around the British Isles. From the twentieth century, Ireland was under the reign of England. The first significant step in the progress of English towards its global status became actual at the end of the sixteenth century. At that time, the number of people whose mother tongue English was between 5 and 7 million, and all of them 
were living in the British Isles. However, if we look numbers between the end of the reign of Elizabeth I (1603) and the beginning of the reign of Elizabeth II (1952), a crucial increase was noticed in these figures. 250 million people were utilizing this language as their mother tongue and the most exciting fact was that the majority were Americans.

Pioneering voyages of English peoplemaybearound the world accounted for the expansion of the English language. It continued till the nineteenth century with colonial expansion. America, Canada, the Caribbean, Australia, and New Zealand, South Africa, later Asia was subjugated by the English language. Adaptation of English as an official and semi-official language by many newly independent states was a significant step in the mid-twentieth century. English is now spoken in all countries of the world. The language has penetrated deeply into all spheres of life across the world. The existence of lingua franca makes global human relations convenient. Several domains, like the computer software industry, have become entirely dependent on it.

D. Crystal [4] defines the present-day status of English as a result of two factors: "The expansion of British colonial power, which picked towards the end of the nineteenth century, and the emergence of the United States as the economic power of the twentieth century. It is the latter factor which continues to explain the world position of the English language today".

D. Crystal [4] summarizes this complicated situation according to the US linguist Braj Kachru's suggestion as following: "...we think of the spread of English around the world as three concentric circles, representing different ways in which the language has been acquired and is currently used" [7, p. 5] (fig. 1).

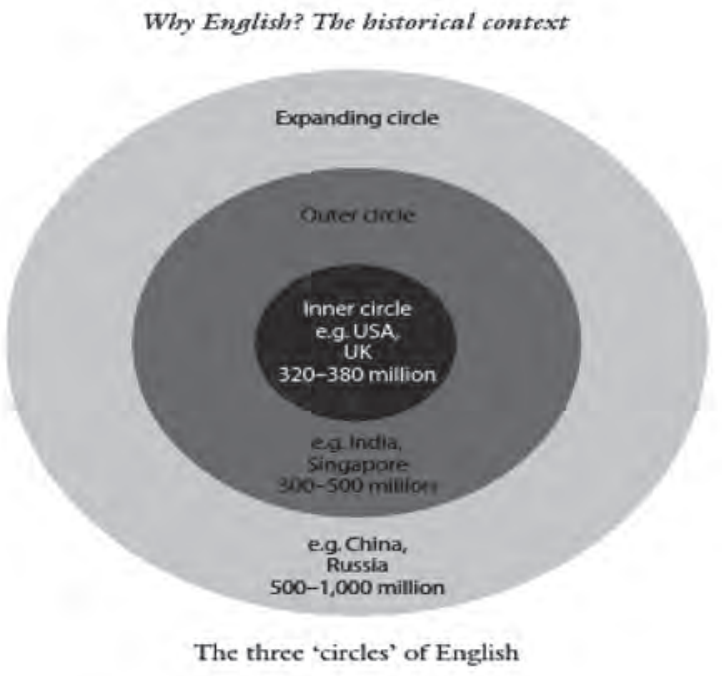

Fig. 1. The three circles of English
4.2. Factors that define the present-day status of English. As we have seen, the emergence of global language mainly depends on the political and economic power of its native speakers between the seventeenth and twentieth centuries British colonies around the world greatly affected the language of the state bodies, parliaments, courts and education systems. At the same time, English became a means of communication between different ethnic groups.

If we look through the present-day status of English, it appears to have an unassailable position in the modern world thanks to the above-mentioned features. What are the intrinsic features that set it apart from the other languages and define it as the most appropriate language for carrying global status? Let's investigate some points:

- Rich vocabulary. It is the main peculiarity that distinguishes it from the other languages. According to the largest dictionary of the world "Oxford English Dictionary", officially, there are 615,000 words in 20 volumes. Taking into account technical and scientific words, this figure rises to over a million. By some calculations, every year 8,500 words enrich the English lexicon, in some claims these figures reach even to 20,000. Moreover, active vocabulary is about 200,000 words as compared to German and French. The richness of synonymy, English idioms and phrases make this language convenient to utilize for the noneEnglish speakers (e.g., administrator - receptionist; car - carriage, coach; stewardess - cabin girl; jaunt, tourney, tour, trip, visit, etc.).

- Flexibility - ability to form new words by adding prefixes and suffixes (e.g., booking, conductor, liner, baedeker, catering and so on), by compounding or fusing existing words together (e.g., airport, roomservice, check-in, familiarization trip, aircraft carrier, etc.), by using the same word as both a noun and a verb (e.g., visit, drink, check-in, fly, deal, etc.)

- Grammar - simple grammar sets it apart from other languages. Case forms for nouns, genders, pronouns, and articles are much easier than in other languages.

- Cosmopolitan character - the borrowing of thousands of words from other languages gives a feeling of familiarity to many other languages. For example, the vast majority of the borrowed words are of French origin (e.g., baggage, guide, visa, restaurant, etc.).

To conclude, rich vocabulary, flexibility, simple grammar, cosmopolitan character plays a vital role in defining English as the international language among the other leading languages. Consequently, English keeps its global status in the modern world as a means 
of communication, which in turn serves to people easily interact in all parts of the world.

4.3. Origins of tourism. In the first part of the research, we make an attempt to find the origins of Global English. Now it is essential to have an overview of the history and impacts of tourism to date. From ancient Roman times (seventeenth century), young men from upper classes traveled through Europe on a "grand tour" [8]. Through the Middle Ages, religious pilgrimages became an inseparable part of society.

The word hospitality first appeared in the fourteenth century. It comes from the Latin word hospes, which means guests, hosts, and foreigners. However, the word tourist appeared in print much later in 1772 [9]. W. Theobald emphasizes that the word tour comes from Greek and Latin words for circle and turn, and that tourism and tourist represent the activities of circling away from home, and then returning [10].

The first travel agency, Cox \& Kings, was founded in 1758. Later, in $1841 \mathrm{~T}$. Cook opened the first leisure travel agency. The main target of this agency is to put the Britons into the world to perfect their lives. In 1845, his first commercial packaged tour was introduced to society. It covered cost-effective railway tickets and a printed guide [11]. After the railway travels, the emergence of automobiles was another crucial step taken in the development of tourism. Fast forward to 1952 with the first commercial air flight from London, England, to Johannesburg, South Africa, and Colombo, Sri Lanka [12] a new era in the tourism industry started.

After the two great World Wars (World War I, World War II) industry saw a rapid decline. Later with the emergence of the internet, a new era began in travel services. Through the 2000s, online bookings occupied the world tourism market. By 2014 with brands as Hotels.com, the Hotwire Group, trivago, and Expedia CruiseShip Centers, earning revenues reached over $\$ 4.7$ million [13].

The impacts of the global tourism industry today are impressive and far-reaching.

4.4. Importance of the English Language in the development of tourism management. The fast, worldwide progression of tourism management resulted in the growth of the tourism industry over the last decades. Communication is an integral part of management and advertising. The global status of English makes it as the most important means of communication within the tourism organizations and for tourism management. Consequently, personnel with high-level English knowledge corporate efficiently and succeed in tourism management. Also, language skills help the tourism agencies to do domestic and international tour businesses successfully.

Language plays an essential role in making dialogues and understanding between tourists and tourist facilities. Taking into consideration the global status of the English language alongside its familiarity for all the people all over the world, most of the tourist establishments require employees to speak English in addition to the local language of the country. Ignoring the important roles of the English language may result in the failure of the tourism sector. Therefore, English can be considered as a required communication means. It has a significant impact on the organization's ability to control international activities.

In the development of tourism, the English language also plays the role of a negotiated source of power. Moreover, language is to be understood as a tool, which is utilized to improve the effectiveness of organizations, particularly in tourism organizational communication. The English Language is a source that comprises all aspects of human life. Furthermore, the role of the language in organizational change is important. However, it can be concluded that language is essential to create a network of tourism.

The success of any tourism organization of any country depends on the ability to interact productively with international tourists or customers, suppliers, and government officials. Miscommunications and conflict can damage relationships, business deals, unsatisfy customers, and frustrate employees. Language or communicative problems can result in negative consequences, and misunderstanding will consequently end up with the loss of potential international tourists.

4.5. English as a language of tourism. The reasons for traveling vary from routine business trips to annual holidays, and from religious pilgrimages to sports competitions. Each journey carries immediate language consequences. According to the last estimations held by the World Tourism Organization, the USA is the leading tourism spender and earner.

In the tourist destinations of the world, the signs in the shop windows are most commonly in English; restaurant menus present the English version. Credit cards, such as American Express and Mastercard, are in English. Safety instructions on international flights and sailings, information about emergency procedures in hotels and directions to major locations are presented in English alongside local languages. Also, thanks to the English notice cards, we get information 
about fastening our seatbelts, finding lifeboat stations, and checking the location of the emergency stairs during our journeys.

There also have been dramatic changes in some tourism destinations in the world. If it was challenging to explore Tokyo in 1985 without an English language map, by 1995, with the help of road signs, it became much more convenient for the visitor. Such a trend is noticeable in all parts of the world.

With the rapid growth of tourism, business tourism discourse becomes one of the most widespread public discourses. Tourism discourse targets to meet the classical requirements of advertising, to capture attention, maintain interest.

Advertisements are described as "a genre of communication that uses words and images to convince people exposed to the advertisement to purchase the product or service being promoted" $[14$, p. 265]. It means that advertisements seduce the readers to purchase the product.

The tourism agencies promote their products by means of the internet. While surfing on the internet, it is evident that though the vast majority of tourism websites are presented in different languages alongside the native one, English is in priority.

Our findings gathered from different sources show that the language of tourism "tend to speak only in positive and glowing terms of services and attractions it seeks to promote" [15, p. 65]. For example, the positive adjectives, like, perfect holiday, fantastic country, exiting activities, can be seen almost in any brochure.

4.6. Tourism lexicology. Division into lexicasemantic groups. While working on this paper in order to get a clear understanding of the tourismrelated vocabulary, we need to make a distinction between different types of semantic groups of tourism lexicology. With this purpose, we tried to analyze different words from different tourist texts (26 terminological units which played a significant role in the 20th century), and divided them into the following lexical-semantic groups (LSGs):

1. Types of tours and tourism include international mass tourism, convention tourism, incentive tourism, familiarization tourism, inclusive tour. This type of LSG encompasses 19,2\% of terms (5 out of 26 investigated terminological units).

2. Types of tourists-includes frequent independent traveler (FIT), camper. It makes $7,7 \%$ of the terms (2 out of 26 investigated terminological units).

3. Tourist organizations - includes World Association of Travel Agencies, - 3,8\% (1 out of 26 investigated terminological units).
4. Documentation, law norms in tourism includes bonding, wallet. Makes 7,7\% of terms ( 2 out of 26 investigated terminological units).

5. Accommodation - includes camping, chalet, moderate tourist class hotel, which comprises $11,5 \%$ of terms (3 out of 26 investigated terminological units).

6. Types of restaurants - includes fast-food restaurant, Hot-Shoppe. It makes $11,5 \%$ of terms (3 out of 26 investigated terminological units).

7. Provision of fare (food) - car hopping, "me too" breakfast, French toasts, omelet(te), sandwich. It makes $19,2 \%$ of terms ( 5 out of 26 investigated terminological units).

Investigation shows that the development of tourism terminology is based on the heritage of antic English lexicology. For example, modern lexicological unit convention tourism comes from the Latin word conventio or convention, which means meeting, agreement. Nevertheless, by the formation of a new kind of tourism industry in the 20th century, this word received a new sense. These lexical units emerged under the influence of extralinguistic factors. We can appreciate this outcome as a result of the development of the tourism industry.

5. Conclusion. Our investigation has led us to conclude that the emergence of English as a global language has a considerable impact on the tourism industry and management in all countries of the world. However, it also reveals significant problems in communication and misunderstanding.

The paper gives a review of the formation of the global English language after World War II, which is based on D. Crystal's linguistic views.

The development of the tourism industry enhanced the importance of English. Tourism agencies were in search of one language to connect their goals. It was the English to come for help. Besides being the language of power richness of vocabulary, flexibility, simple grammar made it the most suitable for obtaining global status.

In 20th-century tourism, as a global world, industry broadened its power. Innovation with the development of science and technology influenced not only extralinguistic but also linguistic activities.

English for Tourism is a language means utilized for communicating in a particular field of tourism. People working in the sector of tourism can run successful communication among their customers. Compared to other foreign languages, English is considered as a dominant language in both the tourism and hospitality sector. As a global language, English strongly influences the field of tourism. 


\section{References:}

1. Piller, I. (2001). Identity constructions in multilingual advertising. Language in Society. Vol. 30. Issue 2. April 2001, pp. 153-186.

2. Pennycook, A. (1994). The Cultural Politics of English as an International Language. Published March 13, 2017 by Routledge, $390 \mathrm{p}$.

3. House, J. (2003). English as a lingua franca: A threat to multilingualism? Journal of Sociolinguistics. № 7. P. 4.

4. Crystal, D. (2003). English as a Global Language. Cambridge : Cambridge University Press. 212 p.

5. Dann, G.M.S. (1996). Greenspeak: An Analysis of the Language of Eco-tourism, Progress in Tourism and Hospitality Research. Vol. 2, pp. 247-259.

6. Wodak, R. (2009). The Discourse of Politics. in Action: Politics as Usual. Palgrave MacMillan, Basingstoke, 2009. VII. 1252 p.

7. Kachru, B. B. (1985). Standards, codification and sociolinguistic realism: the English language in the outer circle'. In English in the World: teaching and learning the language and literatures / edited by R. Quirk, H. G. Widdowson. Cambridge : Cambridge University Press for the British Council, 2014. Vol. 2. No. 9., pp. 832-839.

8. Chaney, E. (2000). The evolution of the grand tour: Anglo-Italian cultural relations since the Renaissance. Portland OR : Routledge. 426 p.

9. Griffiths, R., Griffiths, G. E. (1772). Pennant's tour in Scotland in 1769. The Monthly Review; or Literary Journal XLVI. 150 p. Retrieved from: Google Books.

10. Theobald, W. F. (1998). Global Tourism (2nd ed.). Oxford, England ; Boston : Butterworth-Heinemann, 1994. XIX. 406 p.

11. T. Cook Group of Companies (2014). Thomas Cook history. Retrieved from: http://www.thomascook.com/ thomas-cook-history/.

12. Flightglobal (2002). Sixty years of the jet age. Retrieved from: http://www.flightglobal.com/features/jet-age/.

13. Expedia, Inc. (2013). Expedia: Annual report 2013. Retrieved from: http://files.shareholder.com/downloads/ EXPE/3546131959x0x750253/48AF365A-F894-4E9C-8F4A-8AB11FEE8D2A/EXPE_2013_Annual_Report.PDF.

14. Holloway, J. C. (2004). Marketing for Tourism. Harlow, Essex : Pearson Education Ltd. $54 \overline{4}$ p.

15. Dann, G. M. S. (1996). The Language of Tourism - a Sociolinguistic Perspective. Oxford : CAB International. XII. 298 p.

\section{АЛізаде Л. ГЛОБАЛЬНЕ ПОШИРЕННЯ АНГЛІЙСЬКОЇ МОВИ \\ ТА ЇЇ ВПЛИВ НА ЛЕКСИКОЛОГІЮ ТУРИЗМУ}

Мета статті - дослідити важливість англійської мови як глобальної мови у професійному контексті туристичної індустрії та ї̈ вплив на лексикологію.

Використані методи і методологія. Для проведення дослідження застосовувалися загальнонаукові і приватні (лінгвістичні) методи. Було відібрано і проаналізовано найбільш популярні запозичені туристичні слова згідноз даними відкритих інтернет-ресурсів. Вивчаючи різні джерела, було проведено низку досліджень слів, узятих у сфері туризму в глобальній англійській мові. Були процитовані різні лінгвісти для визначення статусу англійської мови з оглядом їі історії та ролі в туристичному секторі. Однією з иікавих особливостей иього дослідження стало вивчення етимологічного походження слів і словосполучень, що належать до сфери туризму. Було проаналізовано 26 термінологічних одинищь, пов'язаних із туризмом і взятих із різних джерел, та запроваджено лексико-семантичний поділ для більш чіткого розуміння теми.

Головне наукове нововведення. Стрімкий розвиток технологій, маркетингу, реклами, наук відкриває чималі можливості для поширення мови в усьому світі. Підвищений інтерес до туризму в XXI cm. вважається основним фактором швидкої глобалізаџї англійської мови в останні роки. Цей новий процес, який залитає свій слід у мові, привертає особливу увагу лінгвістів. Узв'язку з иим зростає потреба в нових дослідженнях у зазначеній галузі. Зважаючи на всі фактори, ие дослідження має наукове значення.

У статті були отримані такі результати: у ХХ ст. туризм став серйозною глобальною політикою, а отже, з розвитком міжнародного масового туризму розпочався новий етап у становленні міжнародних туристичних організаиій. Світовий статус англійської мови зіграв вирішальну роль в иьому процесі. Отже, англійська мова набула глобального статусу та широко використовусться різними людьми для розуміння один одного й обміну ідеями. Таким чином, у статті стверджується, що в глобальному світі для спілкування, ведення переговорів та налагодження контактів між туристами і туристичними прачівниками роль англійської мови незамінна.

Ключові слова: глобалізаџія, глобальна мова, туризм, глобальний статус, міжнародний масовий туризм. 